\title{
КРАЄЗНАВСТВО
}

УДК 929.52ЮРК : 94 (477.53)

DOI: https://doi.org/10.33782/2708-4116.2020.2.28

Ірина Петренко

\section{ІСТОРІЯ РОДИНИ ЮРКЕВИЧ-СОКОЛОГОРСЬКИХ В ІСТОРІЇ КОБЕЛЯЦЬКОГО КРАЮ НА ПОЛТАВЩИНІ}

\begin{abstract}
Анотація: У статті йдеться про історію дворянського роду Юркевич-Сокологорських, які проживали на хуторі Ісаїка (належав до села Кустолові Кущі) Кобелящького повіту Полтавської губернії. Будинок Сокологорських зберігся до нашого часу та є свідком багатьох історичних подій. Захоплення викликає постать дворянки Олени Юркевич-Сокологорської, яка мала сміливий і вольовий характер, наважилася двічі вийти заміж за простолюдинів і народити від них дітей. На долю цієї жінки випали трагічні події: розлучення батьків у дитинстві дівчини, двічі була вдовою, смерть дітей, бідність, позбавлення всього майна радянською владою, Голодомор 1932-1933 років, Друга світова війна, повоєнна відбудова й ін. Незважаючи на ие, Олена Юркевич-Сокологорська ніколи не опускала руки, була аристократкою до кіния життя. Ї̈ життя - це приклад стійкості, мужності, незламності духа, внутрішнього спротиву трагічним життєвим обставинам. Пам'sть про свій рід і нині зберігають нащадки родини Сокологорських.

Ключові слова: Юркевич-Сокологорські, дворяни, поміщики, Полтавська губернія, родовий мaєток
\end{abstract}

Протягом тривалого періоду історія дворянства перебувала на маргінесі вітчизняної історіографії. Лише в останні три десятиліття інтерес до вивчення діяльності привілейованої групи суспільства зріс, що зумовлено місцем, яке дворянство займало у системі суспільно-політичних, соціально-економічних і соціокультурних відносин.

Складовою частиною історії України є історія її родів, які своїми добрими справами заслужили на добру пам'ять і визнання. 3 Полтавщини вийшло багато відомих родів, які своєю працею сприяли економічному, соціальному, культурному й національному розвиткові України. Однією з таких родин є дворянський рід Юркевич-Сокологорських, який вріс корінням у цю землю і представники якого багато корисного зробили для краю. Мешкала родина на хуторі Ісаївка Кобеляцького повіту Полтавської губернії.

Метою даної статті є на основі використання нових документів дослідити історію родини Юркевич-Сокологорських у Кобеляцькому краї на Полтавщині; проаналізувати життєві обставини цієї сім'ї, зокрема представниці роду Олени Юркевич-Сокологорської.

\footnotetext{
"Петренко Ірина Миколаївна - доктор історичних наук, професор, завідувач кафедри педагогіки та суспільних наук ВНЗ Укоопспілки «Полтавський університет економіки і торгівлі»; ORCID: https://orcid.org/0000-0002-2994-3833; e-mail: poonsku@ukr.net
} 
Нині хутір Ісаївка - мальовничий український куточок, що розташований за 3 км від смт. Білики Кобеляцього району Полтавської області. Нині хутір Ісаївка відноситься до села Кустолові Кущі (Кусткущі) Кобеляцького району Полтавської області. У минулому в цій місцевості відбувалися цікаві історичні події, тут жили неординарні постаті з різними долями. Певною мірою історія хутора - це історія доль людей, які там мешкали. Будинок родини Юркевич-Сокологорських і нині існує на хуторі Ісаївка, хоча він занепадає, нині там мешкає лише кілька родин. Важко дивитися на покинуті та занедбані хати, які повільно руйнуються. Хутори поступово зникають з мапи України, а з ними у небуття йде історія України та її родів. У вирі подій будинок Юркевич-Сокологорських вистояв, хоча й зазнав змін, і в ньому нині живуть люди. Він є свідком багатьох подій - катаклізмів, війн, революцій, репресій тощо. Історія будинку - це історія роду Юркевич-Сокологорських, нащадки якого проживають і зараз недалеко від нього.

Рід Сокологорських відомий в Україні. Є свідчення, що цей рід має козацьке походження. У 12 томі енциклопедії «Полтавіка» йдеться про Сокологорських як рід священиків і благодійників Зокрема, відомо про Дмитра Сокологорського, який народився у 1835 р., закінчив Полтавську духовну семінарію у 1855 р. Був священиком і служив настоятелем церкви у м. Кобеляки ${ }^{1}$. У книзі «Список дворян, внесенных в дворянскую родословную книгу Полтавской губернии за 1802-1907 годы» теж є свідчення про рід Сокологорських як дворянський рід, більшість чоловіків якого були військовими ${ }^{2}$. Відомо, що багато представників цього роду були чиновниками та службовцями.

Про присутність представників цього роду у Кобеляцькому краї свідчать архівні документи. Зокрема, у формулярних списках Кобеляцького рекрутського повітового присутствія за 1846 р. відомо про поміщицю, дружину губернського секретаря Софію Петрівну Сокологорську, яка віддала в рекрути до російської армії селянина з села Іванівка Нестора Гончаренка ${ }^{3}$ у цьому ж документі згадано і поручика Івана Микитовича Сокологорського, який віддав у рекрути селянина Івана Первосласенка з села Байдалівка Кременчуцького повіту ${ }^{4}$. Це дає підстави стверджувати про присутність поміщиків Сокологорських у Кобеляцькому краї щонайменше з першої половини XIX ст.

Продовжити історію родини Сокологорських маємо змогу завдяки письмовим спогадам Олександра Соболя ${ }^{5}$ мати якого Олена Соболь (Юркевич-Сокологорська, Киричко) належала до цього відомого роду. Нащадок наприкінці життя написав спогади, які вмістилися на кілька сторінок учнівського зошита, які є безцінним свідченням історії свого роду. Цей рукопис, який має кілька екземплярів, зберігається у його родини та місцевого громадського діяча Анатолія Ратаєва, котрий придбав його родовий дім. Анатолій Ратаєв передав цей екземпляр рукопису Авторові цієї статті, прочитавши який і виникла ідея підготувати розвідку. Автор статті цей рукопис передала на зберігання у Державний архів

\footnotetext{
${ }^{1}$ Полтавіка. Полтавська Енциклопедія: у 12 томах. Т. 12: Релігія і церква на Полтавщині / Гол. ред О.А. Білоусько. Полтава: Вид-во «Полтава», 2009. С. 353.

${ }^{2}$ Список дворян, внесенных в дворянскую родословную книгу Полтавской губернии за 1802-1907 годы / ред. А.А. Шумков, Сост. В.В. Коротенко, И.Г. Рыклис, М.Ю. Чиркова, А.И. Якименко. Москва: «Старая Басманная», 2013. C. 536.

${ }^{3}$ Державний архів Полтавської області (далі - ДАПО). Ф. 981. Оп. 1. Спр. 6. Арк. 53.

${ }^{4}$ ДАПО. Ф. 981. Оп. 1. Спр. 6. Арк. 33.

${ }^{5}$ Спогади Соболя Олександра Андрійовича // Приватний архів Ратаєва Анатолія. 8 арк.
} 
Полтавської області. Ці спогади стали основною джерельною базою для підготовки даного дослідження. Нині вони вперше вводяться до наукового обігу.

Джерелами для підготовки цієї розвідки стали й інтерв'ю $з$ дочкою Олександра Соболя - Любов'ю Соболь, яка нині мешкає у смт. Білики Кобеляцького району Полтавської області. Любов Олександрівна поділилася родинними світлинами, спогадами, документами, які вона зберігає як пам'ять про свій дворянський рід.

Свою історію родини Сокологорських розпочинаємо з Софії Сокологорської (1840 р.н.), яка у 1861 р. народила дочку Віру Василівну. Віра вийшла заміж за поміщика Григорія Юхимовича Юркевича - поляка, який був підприємщем, мав у м. Лодзь спиртовий завод.

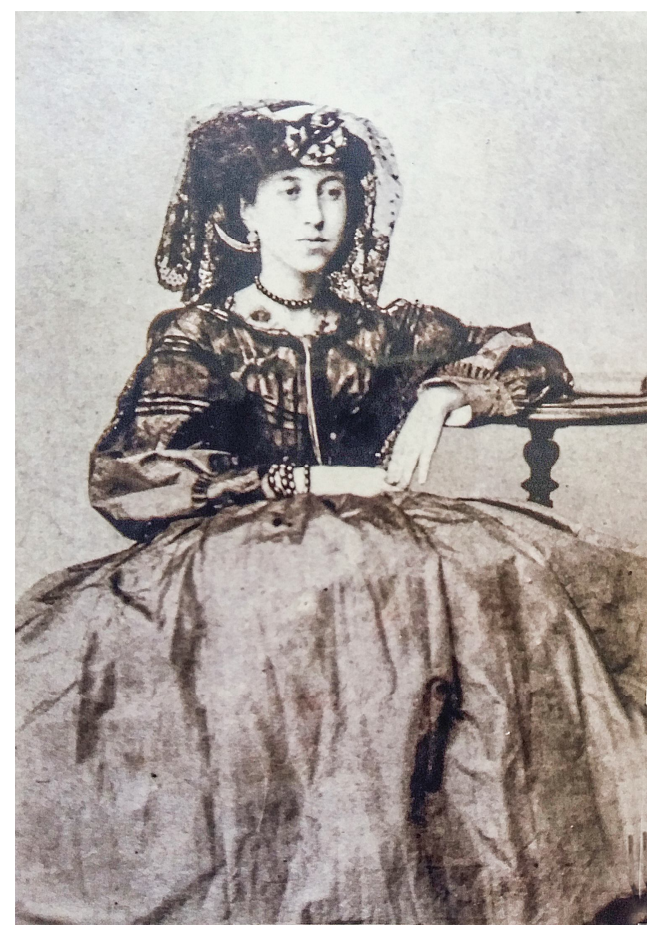

Рис. 1. Софія Сокологорська (родинний архів)

У подружжя була єдина дочка Олена Григорівна Юркевич-Сокологорська, народжена 1885 р. В Ісаївці на височині серед соснового лісу, де було чудове повітря, стояв їхній одноповерховий будинок на 22 кімнати. Будинок було зведено у 1870 p. і становив 620 квадратних метрів, складався із основної будівлі, прибудованої кухні, закритої галереї, тамбуру та підвалу ${ }^{6}$. Дім був цегляним на вапняному розчині, стіни були дерев'яними, обкладеними цеглою, дерев'яні перекриття, підлога була дощатою сосновою, залізний дах, соснові віконні рами, фільончасті двері, польські печі та плити ${ }^{7}$ (оскільки Григорій Юркевич був поляком, то він привніс польські елементи у будинок). В одній частині жили поміщики, в іншій - прислуга й інші працівники господарства.

У маєтку було багато будівель - комора, дві клуні, чотири господарських сараї, два вхідних льохи, кошара та свинарник ${ }^{8}$.

Біля будинку був ставок, поруч з яким був прекрасний сад. Господарство було великим - 18 пар волів, 12 коней, 24 корови, молодняк свині, вівці. Обслуговували їх в основному мешканці Ісаївки, де було 30 хат, і працівники з інших населених пунктів. У господарстві жила єврейська громада, які були молочниками, тримали корів і продавали молокопродукти.

Олена Юркевич-Сокологорська закінчила Полтавську жіночу гімназію. Володіла російською, польською та французькою мовами. Дівчина любила подорожувати і після

\footnotetext{
${ }^{6}$ Архів Управління Служби безпеки України в Полтавській області (далі - усБУ в Полтавській області). Спр. 17297. Арк. 10.

${ }^{7}$ Архів УСБУ в Полтавській області. Спр. 17297. Арк. 16-16зв.

${ }^{8}$ Спогади Соболя Олександра Андрійовича // Приватний архів Ратаєва Анатолія. Арк. 1.
} 
закінчення навчання ії рідні придбали путівку за 98 рублів з Петербурга Балтійським морем через Німеччину, Францію, Італію, Грецію, Боснію, Хорватію, Словенію і Чорним морем повернулася до Одеси.

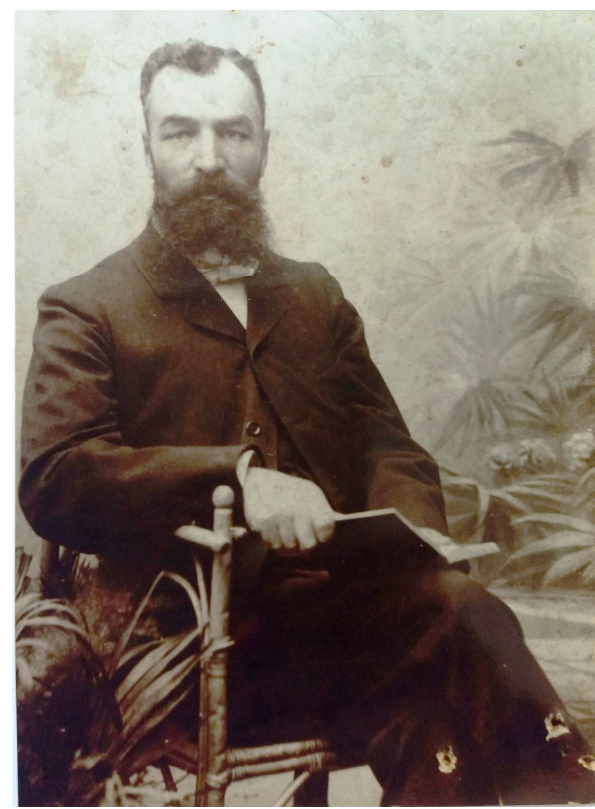

Рис. 2. Григорій Юркевич. 1860 р.

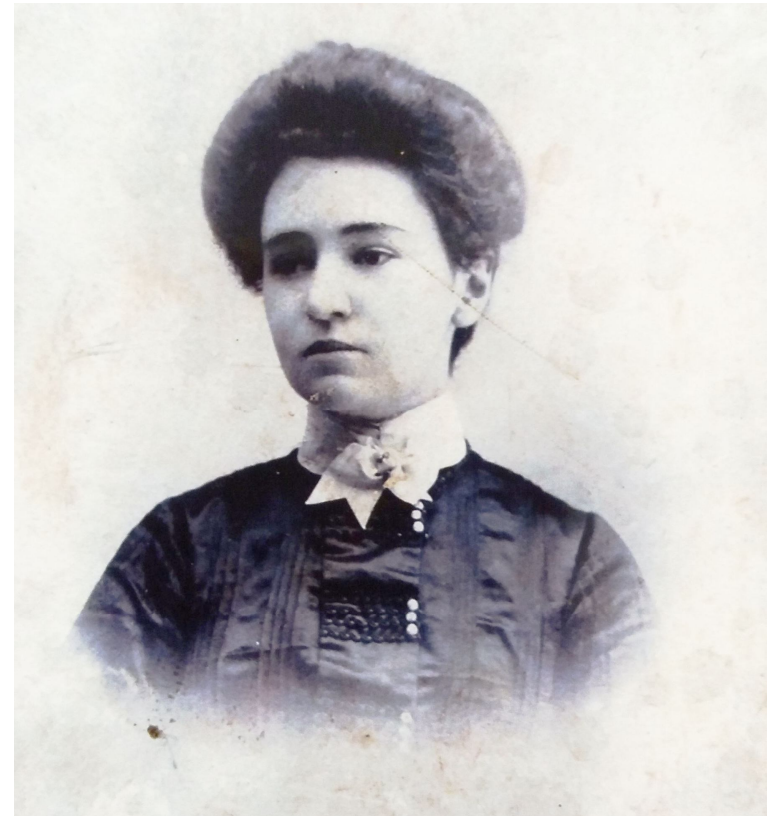

Рис. 3. Віра Юркевич-Сокологорська (родинний архів)

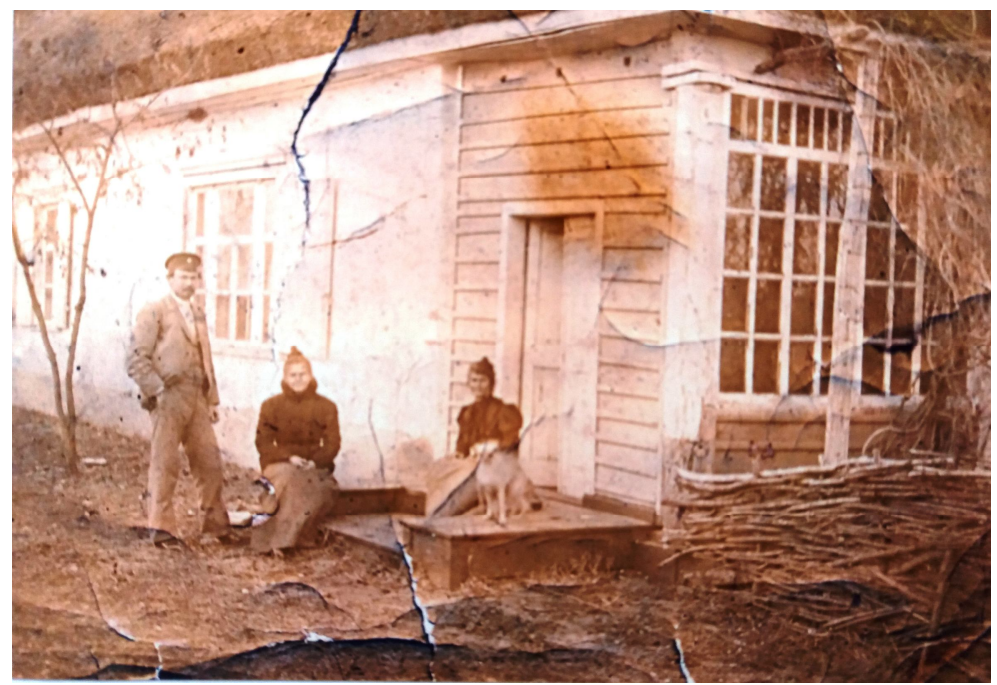

Рис. 4. Будинок Сокологорських на хуторі Ісаївка. Віра Сокологорська (справа), Олена Юркевич-Сокологорська і працівник господарства (родинний архів) 


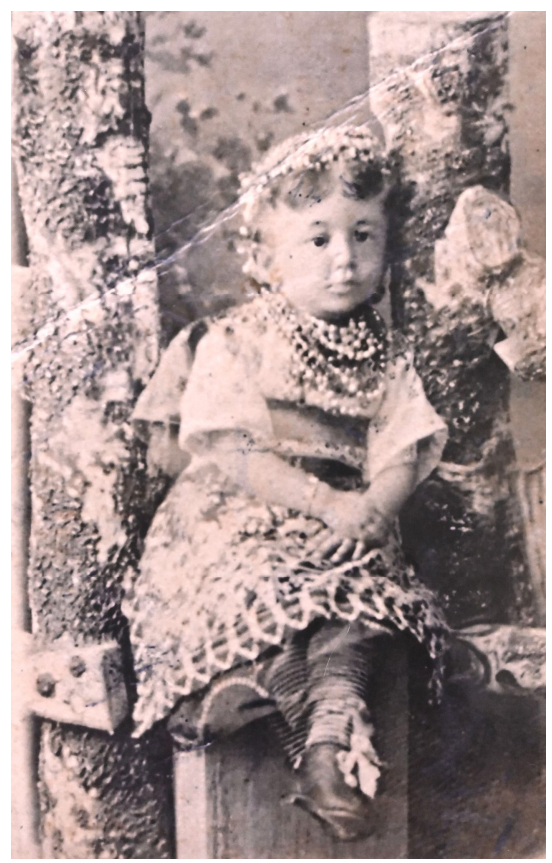

Рис. 5. Олена Сокологорська у віці 4 років.

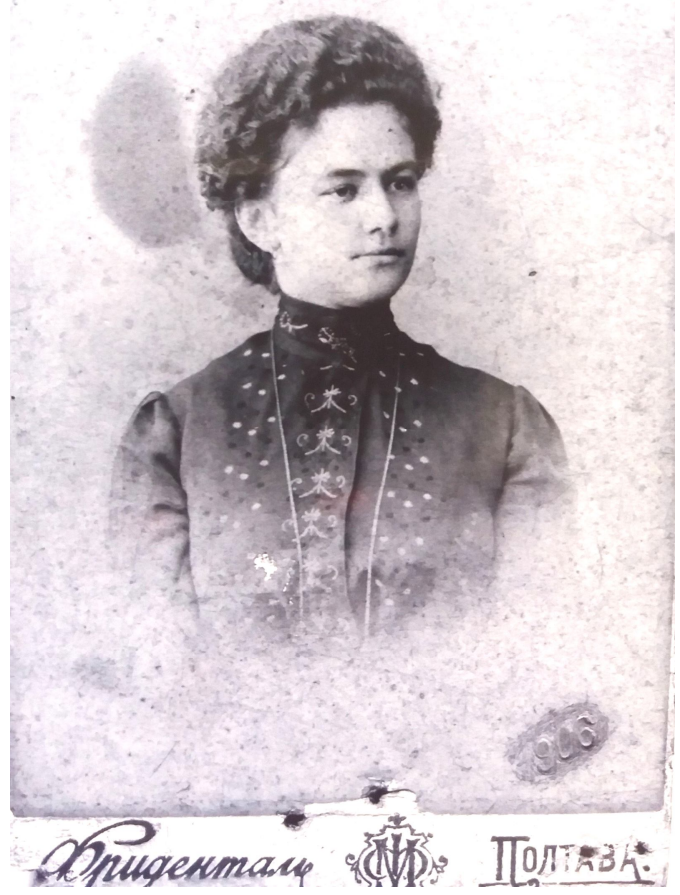

Рис. 7. Олена Юркевич-Сокологорська. 1906 р.

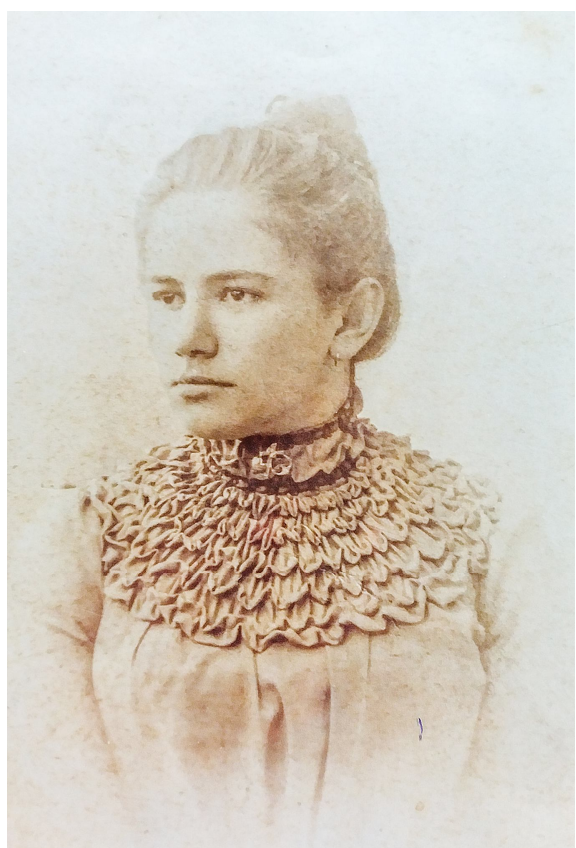

Рис. 6. Олена Сокологорська у віці 16 років.

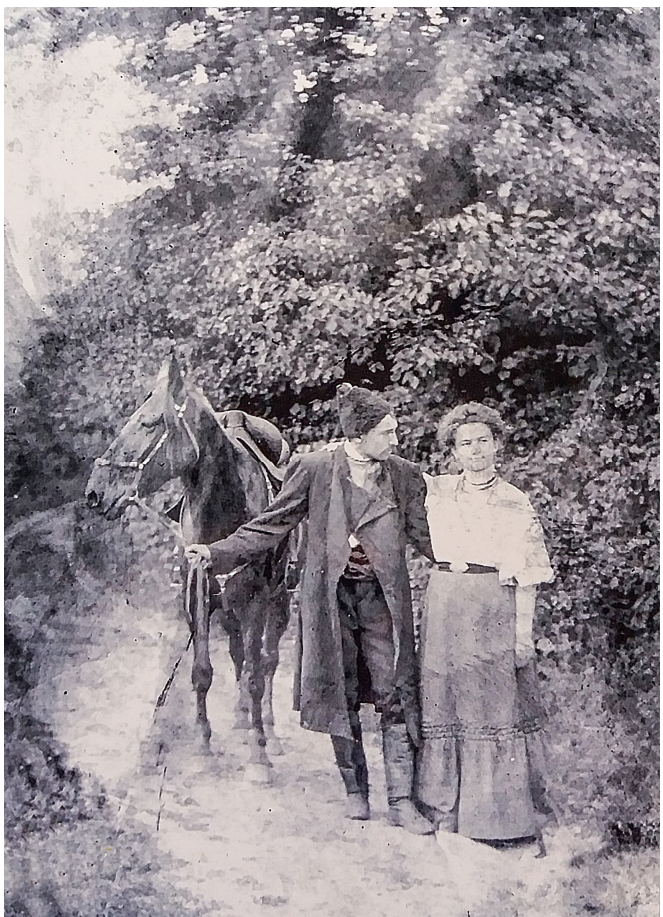

Рис. 8. Дмитро Ліщина й Олена ЮркевичСокологорська (родинний архів)

(родинний архів) 
Дружила Олена з сином місцевого поміщика Дмитром Ліщиною, який жив у Біликах. Він був мисливцем і вони разом з Оленою їздили на полювання верхи на конях, каталися на човнах, розважалися. Після повені на річці Ворскла з поваленої у воду осики стріляли рибу у воді.

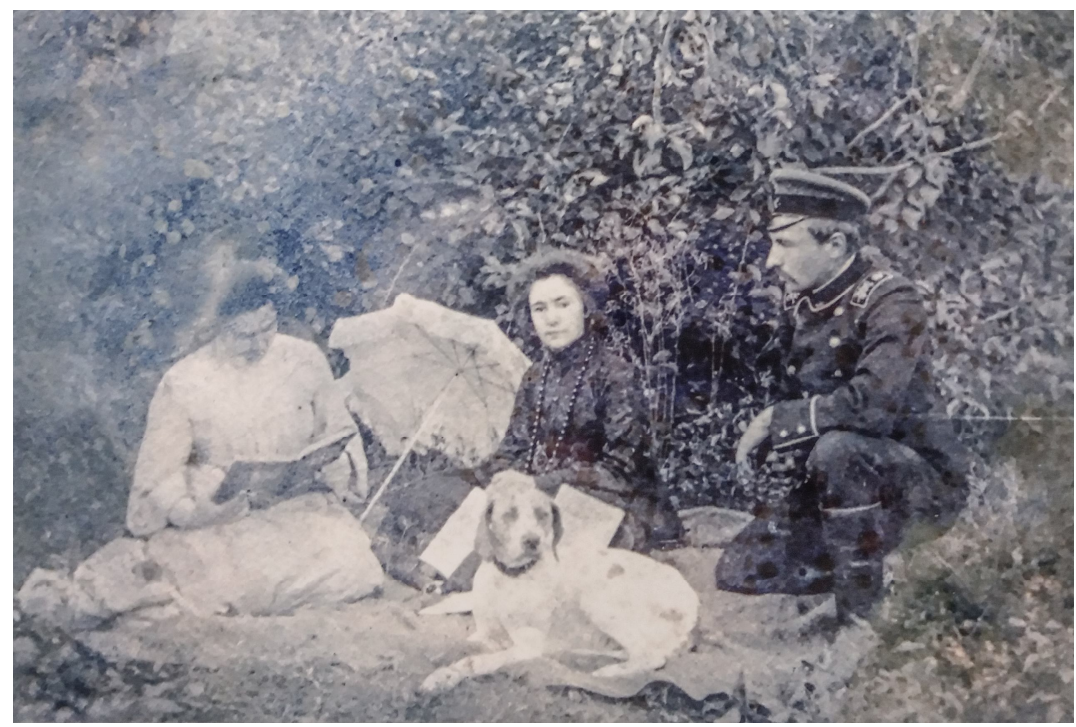

Рис. 9. Олена Юркевич-Сокологорська (зліва), Дмитро Ліщина та його сестра (родинний архів)

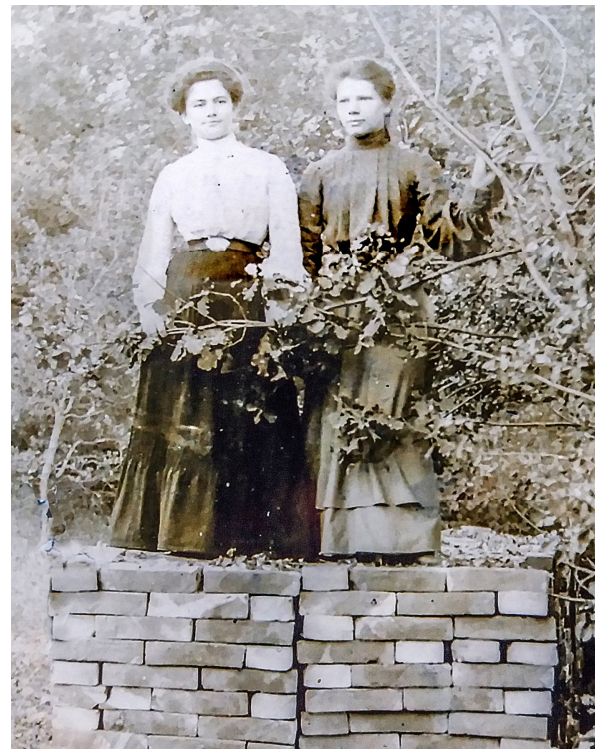

Рис. 10. Олена Юркевич-Сокологорська 3 дочкою пана Ліщини (родинний архів)
Згодом, всупереч бажанню своєї матері, Олена подружилася з Киричко Тихоном Володимировичем, який працював конюхом у Віри Василівни. У 1909 р. молоді одружилися. Мати Олени погодилася поїхати до священика Успенської церкви Грановського та домовитися про вінчання дочки. Родина Сокологорських була у гарних взаєминах з Грановським - священик дружив з Вірою Василівною, а Олена - 3 його дочкою. Грановський за вінчання запросив 50 руб. Це було дуже дорого, адже тоді пара волів коштувала 50 руб. Віра Василівна не погодилася. Поїхала до священика в Санжари і той погодився повінчати молодих за 25 руб.

Коли Олена вийшла заміж за Тихона, то іï мати розсердилася і не захотіла жити разом 3 ними. Вона купила в Ісаївці будинок братів Тимошенко, який був недобудований. Цей будинок

\footnotetext{
${ }^{9}$ Спогади Соболя Олександра Андрійовича // Приватний архів Ратаєва Анатолія. Арк. 2.
} 
заклав 1908 р. батько Тимошенко для синів. Закінчував його будівництво вже Тихін, який 3 родиною наприкінці 1909 р. перебрався жити в нього. Разом з цим будинком Віра Сокологорська відписала молодим 12 га землі разом з озером, яке існує і зараз.

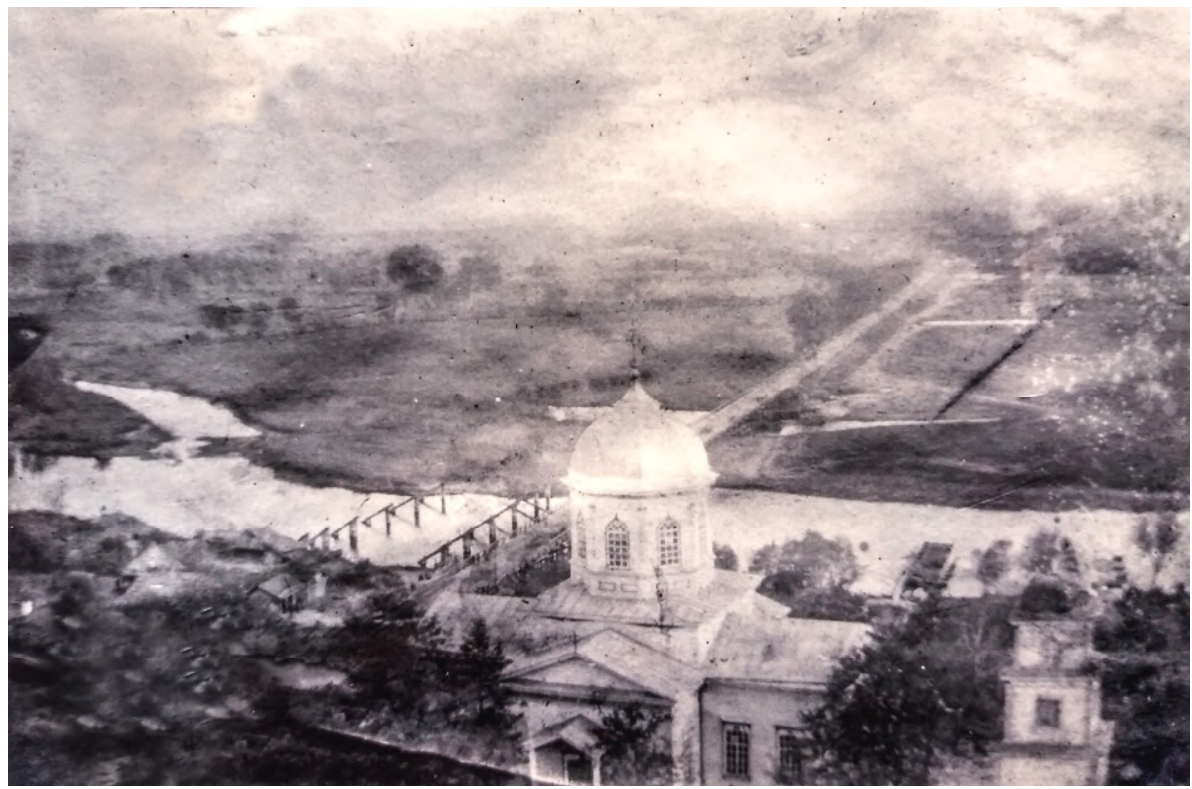

Рис. 11. Успенська церква у Біликах (родинний архів)

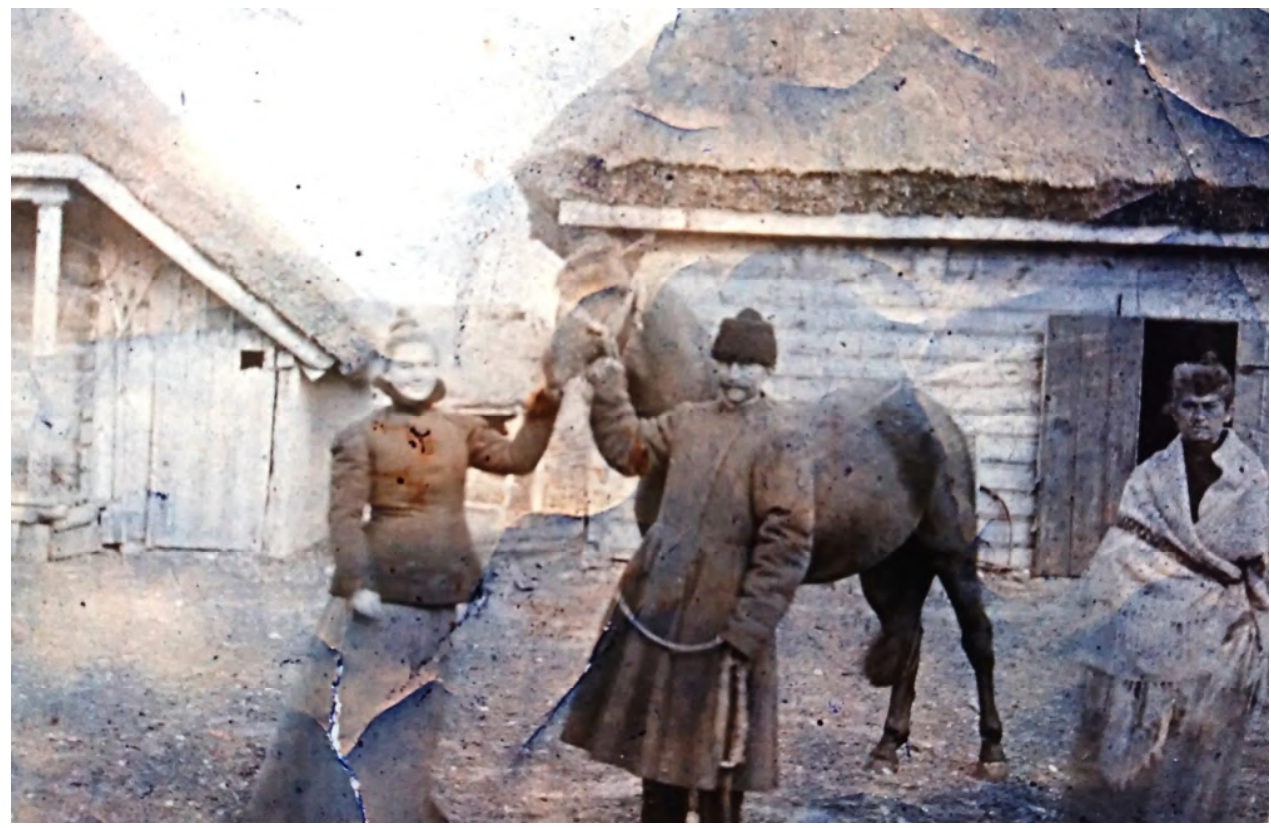

Рис. 12. Олена Юркевич-Сокологорська (зліва), конюх Тихін Киричко та Віра Сокологорська (родинний архів) 


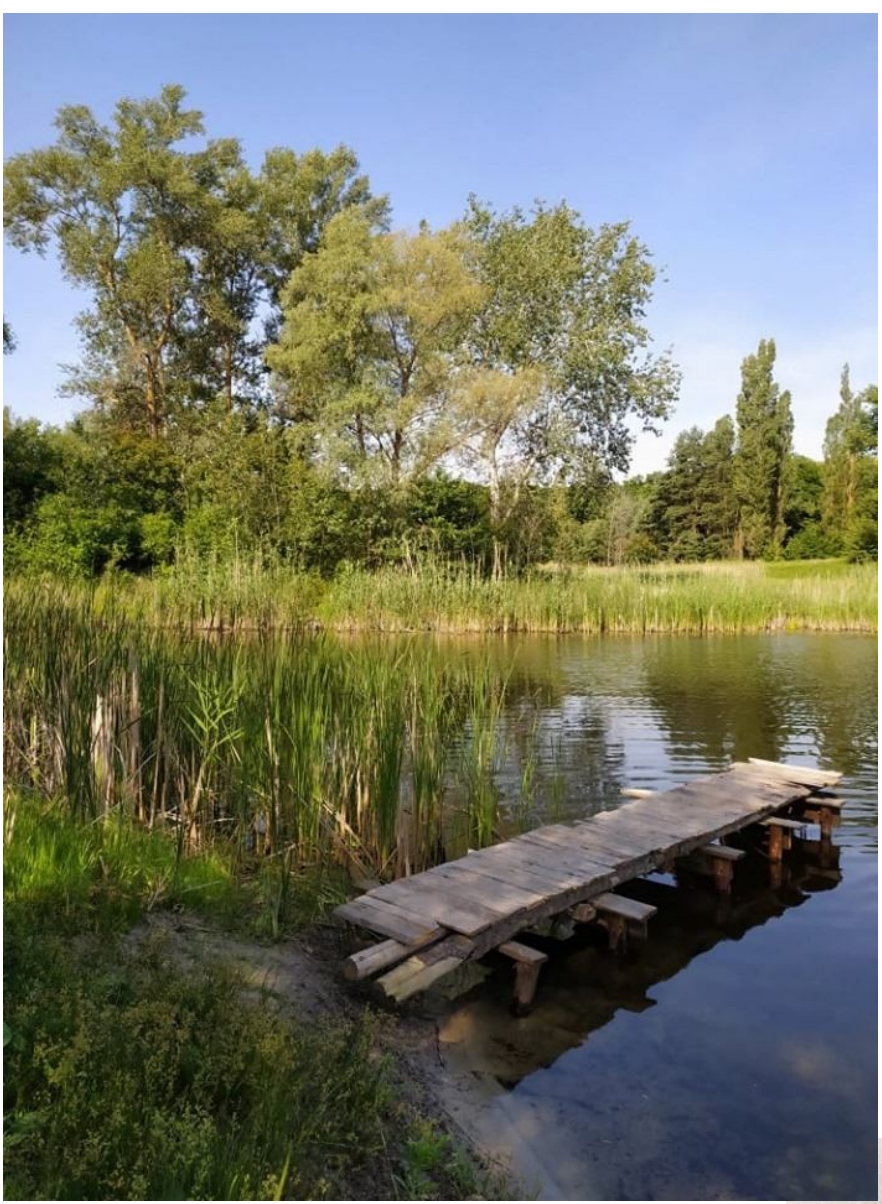

Після закінчення будівництва подружжя перебралися жити у цей будинок. Він був покритий очеретом, поруч була комора та господарські будівлі - клуня, два рубаних приміщення для свиней, колодязь, а також був сад ${ }^{10}$. На клуні постійно гніздилися лелеки. Цей будинок пізніше був неодноразово перебудований, і нині стоїть в Ісаївці.

у Олени Григорівни 3 Тихоном Володимировичем народилися троє дітей: Володимир (1910-1941), Вipa (19111998), Віктор (1912-1943). у 1914 р., коли почалася Перша світова війна, Тихона забрали на фронт. Там його було поранено в спину, він повернувся додому і незабаром помер.

Рис. 13. Озеро на хуторі Ісаївка. Сучасний вигляд. (фото Оксани Павелко, 2020 р.)

Залишилася Олена 3 трьома дітьми і все господарство лягло на її плечі. Допомагав їй по господарству сусід Григорій Саліченко, який не мав власного господарства.

Життя та побут у панській садибі був влаштований наступним чином: чоловіки орали, сіяли, косили траву. Пшеницю і жито косили, складали 8-10 снопів залежно від урожаю. Все звозили на хутір і складали у копиці. Взимку в клуні молотили ціпами.

Рис. 14. Тихін Киричко (1884-1916?) (родинний архів) $\rightarrow$

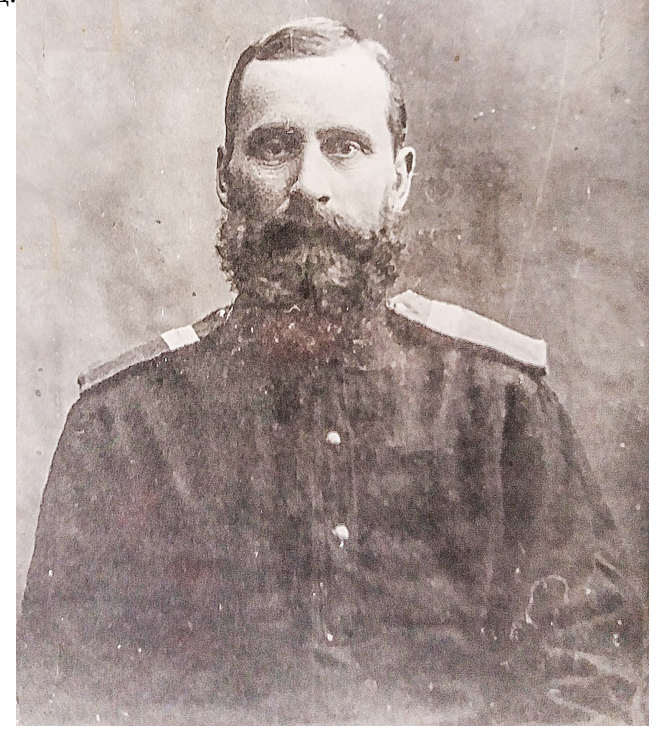

${ }^{10}$ Спогади Соболя Олександра Андрійовича // Приватний архів Ратаєва Анатолія. Арк. 3. 


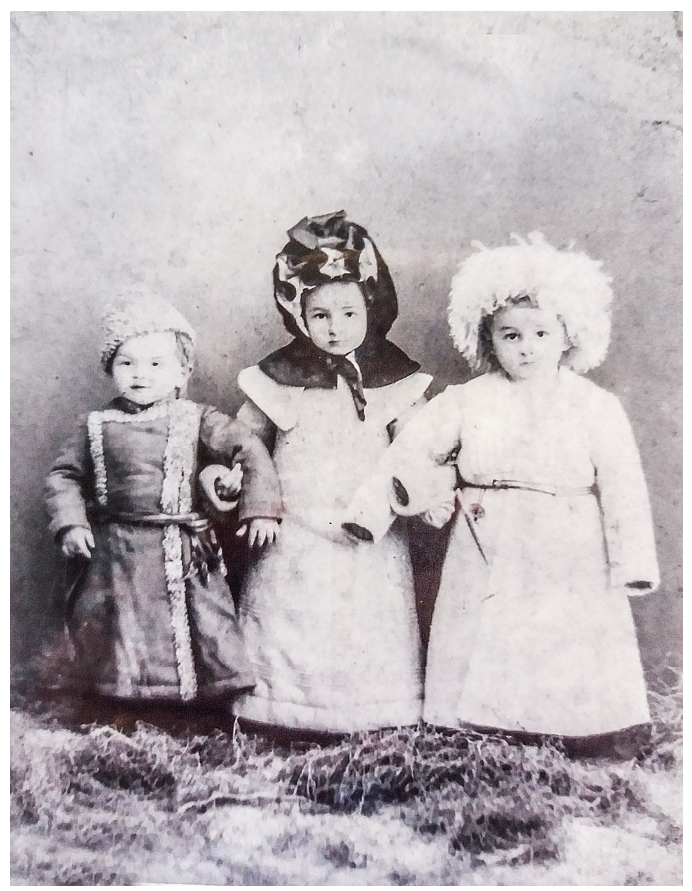

Рис. 15. Діти Тихона й Олени: Віра, Володимир, Віктор (родинний архів)

Зерно відвозили на залізничну станцію Санжари, де здавали у млин, власником якого був німець. Звідти привозили вже борошно. Жінки у господарстві Сокологорських саджали та пололи городи, сушили сіно, в'язали снопи, зимою пряли нитки, 3 яких робили полотно. Всі ці працівники були на утриманні Віри Сокологорської. Були й постійні працівники, зокрема, воловники, конюхи, доярки, кухарі, домогосподарки. Багато мешканці сусідніх із Ісаївкою сіл мали роботу та заробіток завдяки панам Сокологорським. Крім того, до працівників завжди було добре ставлення, про що потім згадували місцеві мешканці та їхні нащадки.

Олена Григорівна розповідала такий випадок: в євреїв, які жили в їхньому господарстві та реалізовували молокопродукти, був спеціальний льох, де вони зберігали молокопродукти. Ляда над льохом була у вигляді зрубу, закривалася на замок. Молоді хлопці бувало піднімали ляду разом зі зрубом, набирали масла, сметани, і потім усе ставили на місце, ніби нічого не відбулося.

У зимові вечори, коли був вільний час, та на свята, чоловіки й жінки Ісаївки збиралися у Віри Василівни Юркевич-Сокологорської: грали в карти, розмовляли, вечеряли, розважалися.

У 1917 р. Олена Григорівна прийняла до себе жити убогу дівчинку Наталію Соболь, яка ходила по селу та просила милостиню. Дівчина допомагала по господарству, натомість ї̈ годували й одягали. На Різдво дівчина захотіла відвідати батьків, які мешкали у с. Чорбівка Кобеляцького повіту Полтавської губернії. Олена Григорівна запрягла сани i поїхали до батьків дівчини. Вона прихопила з собою харчі для гостинців.

Коли Олена Григорівна зайшла до будинку, то побачила жахливу бідність. Посеред кімнати був стіл і лава, які були нічим не покриті. Старий чоловік Яків Софронович Соболь лежав на грубці, дружина Марія поралася біля горщиків, на лавці сиділо троє молодих хлопців. Олена Григорівна віддала гостинці. Вони гуртом швидко все з'їли. Батько почав дорікати Наталі, що вона пішла з дому і тривалий час не повідомляла про себе. Наталя відповіла, що їй у тітки дуже добре живеться і вона хотіла повернутися до неї знову. Батько не заперечував ${ }^{11}$.

Олена Григорівна запропонувала взяти одного з хлопців у найм. Вона обрала Андрія Соболя, який народився у 1895 р., і був молодший за Олену на 10 років. Він мав почат-

\footnotetext{
${ }^{11}$ Спогади Соболя Олександра Андрійовича // Приватний архів Ратаєва Анатолія. Арк. 4.
} 
кову освіту, закінчив 3 класи школи ${ }^{12}$. Андрій служив у кавалерії, а їй потрібен був той, хто вмів коней запрягати. Хлопець служив рядовим 16 запасної піхотної бригади й успішно закінчив курс військової служби кінним ординарцем ${ }^{13}$.

Приїхали на Ісаївку Олена Григорівна, Андрій і Наталія. Яків і Марія Соболь, брати Андрія - Купріян, Захар і Лука залишилися вдома. Андрій Якович став старанно допомагати Олені по господарству. Возили з лісу хмиз і дерева на підводах, запряженими волами.

Яків Соболь чекав місяць-другий на сина та дочку, а потім взяв палицю в руки і пішов шукати своїх дітей ${ }^{14}$. Розпитав людей, де живе Сокологорська, прийшов до Олени Григорівни, зайшов у будинок, побачив сина Андрія, який сидів за столом під образами, де було місце господаря дому. А Олена сказала, що може він і буде господарем. Жінка пригостила Якова Софроновича й Андрія, а сусід Григорій Саліченко склав їм компанію. Згодом Соболь Андрій одружився з Оленою Григорівною. Подружжя вирішило взяти спільне прізвище Соболь.

Олена Юркевич-Сокологорська потребувала сильних чоловічих рук у господарстві, тому вибір Андрія Соболя, який вмів вправно вести господарство, був удалим і цілком зрозумілим. Сільське господарство потребує дбайливого та працьовитого господаря, який був здатен забезпечити догляд за землею і худобою.

Потім настали інші часи. Зі встановленням радянської влади була скасована приватна власність і поміщицьке землеволодіння. Доля роду дворян Юркевич-Сокологорських була типовою, як і тисяч інших поміщиків, передусім, вони позбулися власності.

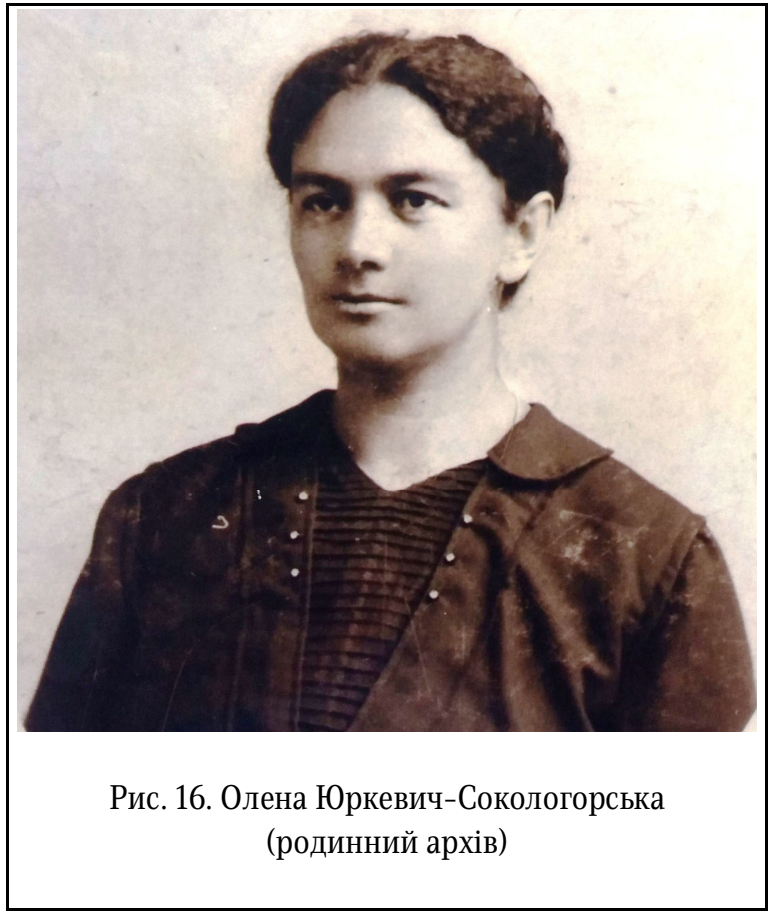

Віру Василівну Сокологорську кинули в Кобеляки до в'язниці, вимагаючи віддати золото. Вона там просиділа більше місяця, врешті-решт зібрала всі золоті речі та віддала. Тоді їі випустили.

Поки господині не було вдома, місцеві мешканці тягнути з хутора все, що кому сподобалося. Поки Віра Василівна повернулася, господарство все розтягли. Вона перехвилювалася та сильно захворіла.

Відомий такий випадок. Селянин Дубина Степан Іванович взяв із панського маєтку дзеркало, приніс його додому, став тягнути його в хату, а воно було завелике. Він поставив його під сарай, планував обрізати ніжки. Коли на обід заганяли корову, то вона розбила те дзеркало. Розібрали улам-

\footnotetext{
${ }^{12}$ Архів УСБУ в Полтавській області. Спр. 17297. Арк. 13.

${ }^{13}$ Архів УСБУ в Полтавській області. Спр. 17297. Арк. 33.

${ }^{14}$ Спогади Соболя Олександра Андрійовича // Приватний архів Ратаєва Анатолія. Арк. 4зв.
} 
ки дзеркала, селянин вмонтував їх у комин перед піччю. Інші сусіди зробили те саме. Свідки пам'ятали потім уламки того дзеркала в коминах ісаївчан.

У подружжя Соболів народилося 4 дітей: Михайло (1919-1985), Олександр (19202004), Ольга (1922-1927), Григорій (1924-1931). Ольга і Григорій померли в дитячому віці від хвороб.

У 1922 р. матір Віру Василівну Олена Григорівна й Андрій Соболь забрали до себе, вона сильно хворіла й у 1923 р. померла. Похована в смт. Білики. Подружжя Соболів переселилося зі своєї хати у родовий маєток Юркевич-Сокологорських.

Жорстока, антинародна політика більшовиків, вже в травні 1920 р. призвела до всезагального вибуху - повстань козаків і селян. У Кобеляцькому повіті ці повстання очолили Андрій Левченко, Петро Погорілий та інші колишні офіцери царської армії та Української Народної Республіки. На початку 1920-х років ідейні погляди братів Соболів розійшлися. Захар Соболь воював у партизанському загоні Садового проти радянської влади. Приймав участь у нальоті на села Солонці, Маячка, міліцію села Кустолове, де його було вбито помічником міліціонера Оніпком. Майно Захара Соболя було конфісковане на користь радянської влади ${ }^{15}$.

Рідні брати Захара Купріян та Андрій були лояльними до радянської влади, співпрацювали з нею. У період колективізації Андрій Соболь боявся розкуркулення. У 1929 р. його примусили вступити до колгоспу, забрали волів, корову, коней і невеликий господарський інвентар - плуг, сівалки, віялку, бричку, віз, сани. Примусили здати комору та клуню у колгосп. Андрія Соболя обрали головою колгоспу. Брат Купріян теж став головою колгоспу.

На той час у колгоспах тримали коней для армії. Трапився такий випадок. Був один молодий жеребець, призначений для армії. Андрій на ньому їздив. Приїхав 3 наради 3 Кобеляк, цей кінь був перегрітим, віддав його конюхам, а ті його напоїли холодною водою і кінь помер. Крім того, у скирті запріло сіно, яке теж було заготовлене для коней Червоної Армії. Андрія стали викликати до суду.

Один хороший знайомий з району порадив Андрію Соболю їхати куди-небудь, інакше його б судили. Андрій покинув сім'ю, поїхав на Дніпропетровщину та влаштувався дорожнім обхідником на залізничному транспорті. У 1930 р. йому пообіцяли квартиру в залізничній казармі, він приїхав і забрав сім'ю. На Дніпропетровщині родина Соболів жила до 1936 р.

у 1931 р. сильно захворів син Григорій і помер. У роки Голодомору у 1933 р. в Чорбівці помер батько Андрія Соболя Яків, а у 1937 р. відійшла у вічність мати Марія ${ }^{16}$.

Коли родина Соболів повернулася додому в Ісаївку, в їхньому будинку жив селянин Ладатко Федосій Никифорович. Сараї використовував колгосп для тримання волів, яких він доглядав. Дім було поділено на дві половини - Ладатко Феодосій залишився жити в одній половині дому, а родина Соболів - в іншій.

Господарство на той час розорилося. У домі була велика бібліотека, яку сусід Григорій Саліченко забрав для розпалки печі в дім. Були там книги як додаток до журналу «Відродження», який Віра Василівна виписувала кілька років поспіль.

\footnotetext{
${ }^{15}$ Пугач О. Отаман Левченко: історико-документальний нарис. Київ: Видавництво Ліра-К, 2020. С. 391.

${ }^{16}$ Архів УСБУ в Полтавській області. Спр. 17297. Арк. 13зв.
} 
У будинку нічого не залишилося, окрім двох диванів, шаф для борошна, столів, стільців. У родини Соболів тривалий час зберігалися сімейні старовинні речі - фарфорова керосинова лампа, срібний підстаканник з написом «Елене Григорьевне от Мстислава и Богдана Пржевальских», який вона привезла з Польщі у 18-річному віці. Ложки, вирізані 3 груші у вигляді щуки, яка тримає ложку в зубах, досі зберігаються у членів родини Соболів. Збереглася й мідна ступка, якою користувалося кілька поколінь родини й нині продовжують використовувати ї̈ у господарстві правнуки Олени Юркевич-Сокологорської.

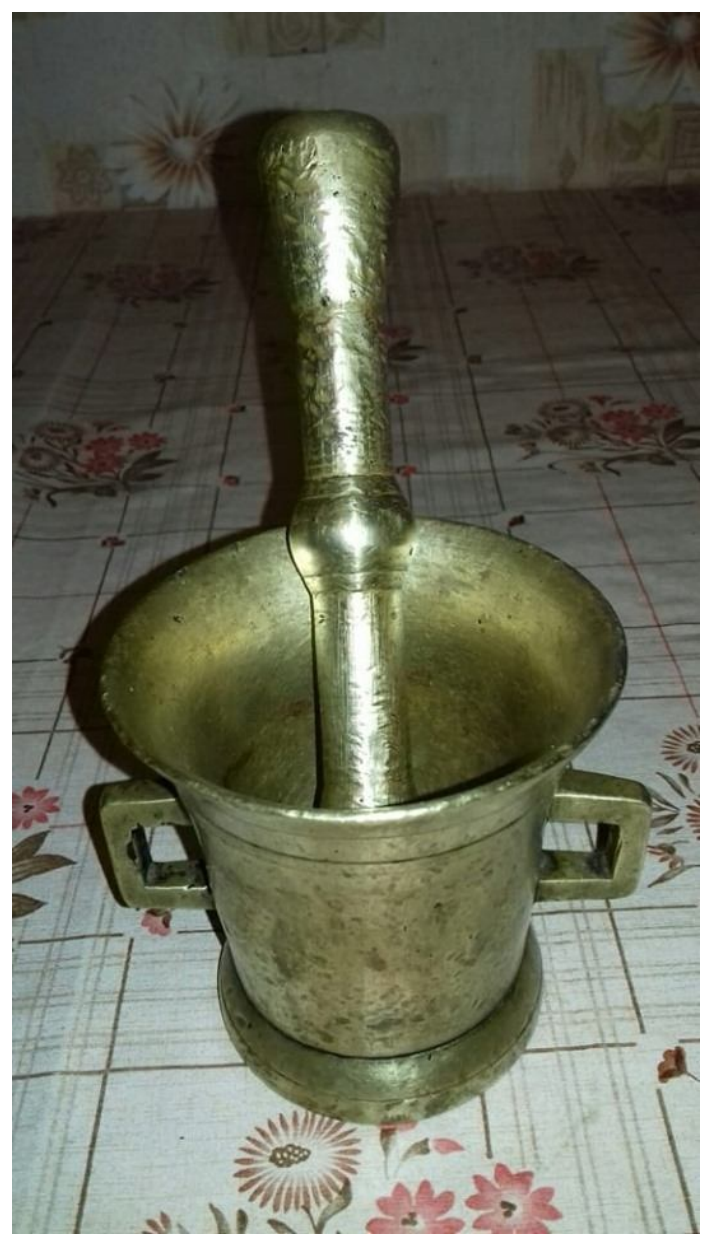

Рис. 17. Мідна ступка родини Юркевич-Сокологорських.

Фото Лесі Близнюк (правнучки Олени Юркевич-Сокологорської). 2020 р.

Діти Олени Григорівни: від першого шлюбу - Володимир Киричко працював у паровозоремонтному депо Полтави зварювальником, був одруженим, мав дочку Нелю; Віра Киричко (Адамова) - була домогосподаркою, проживала в смт. Білики і мала синів Бориса й Олександра; Віктор - працював зварником у Полтаві і мав сина Олександра. Діти від другого шлюбу - Михайло служив на залізниці, мав двох синів Юрія та Валерія; Олександр - працював на ТЕС у Полтаві, а потім у Біликах, мав двох дочок - Любов і Світлану. 
so Antiquities of Lukomorie $\infty$

2020 - № 2 (2)

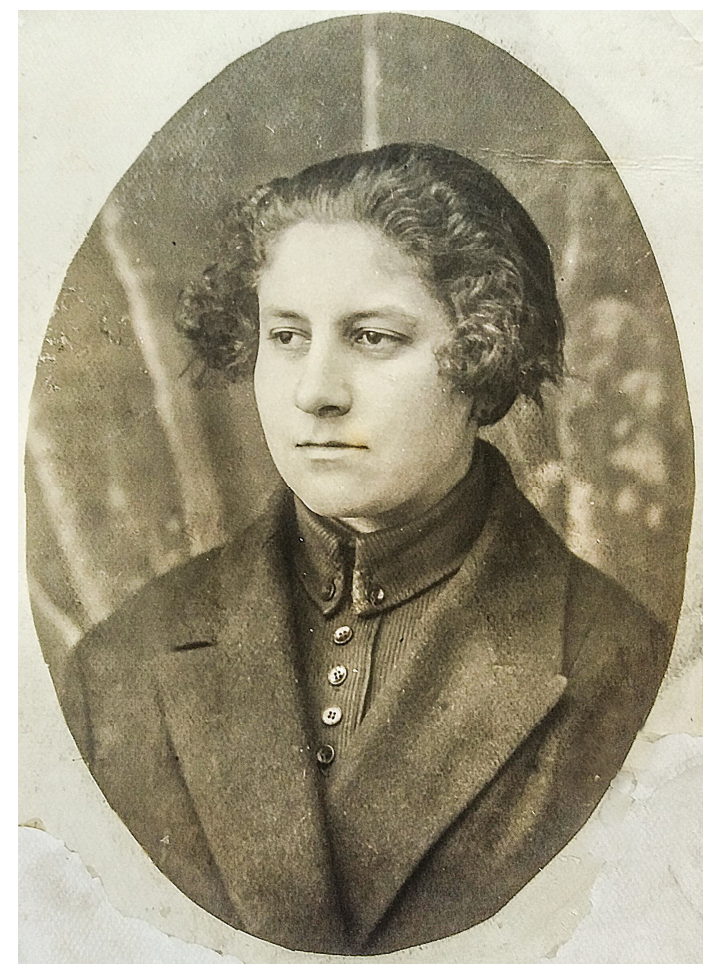

Рис. 18. Віра Киричко (Адамова) (1911-1998) (родинний архів)
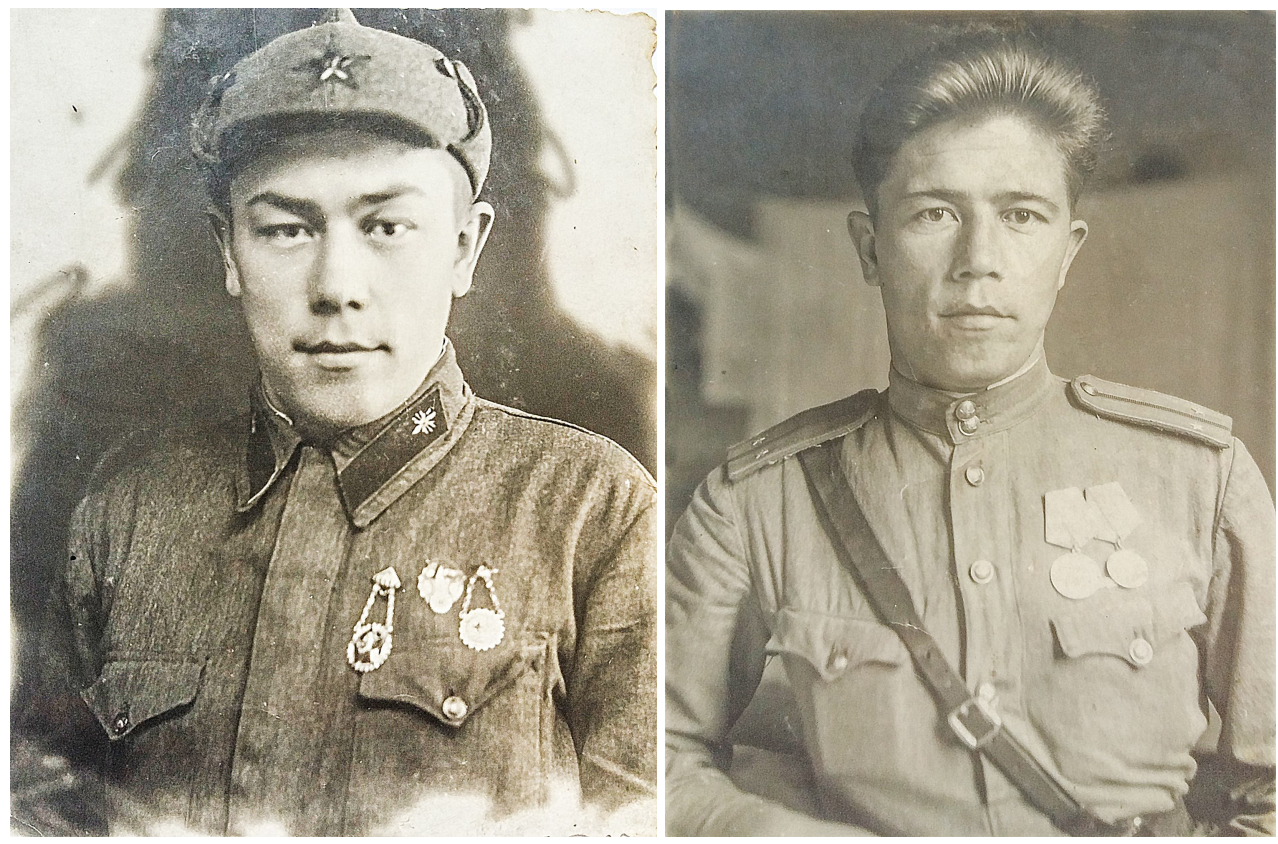

Рис. 19-20. Михайло Соболь (1919-1985) (родинний архів) 


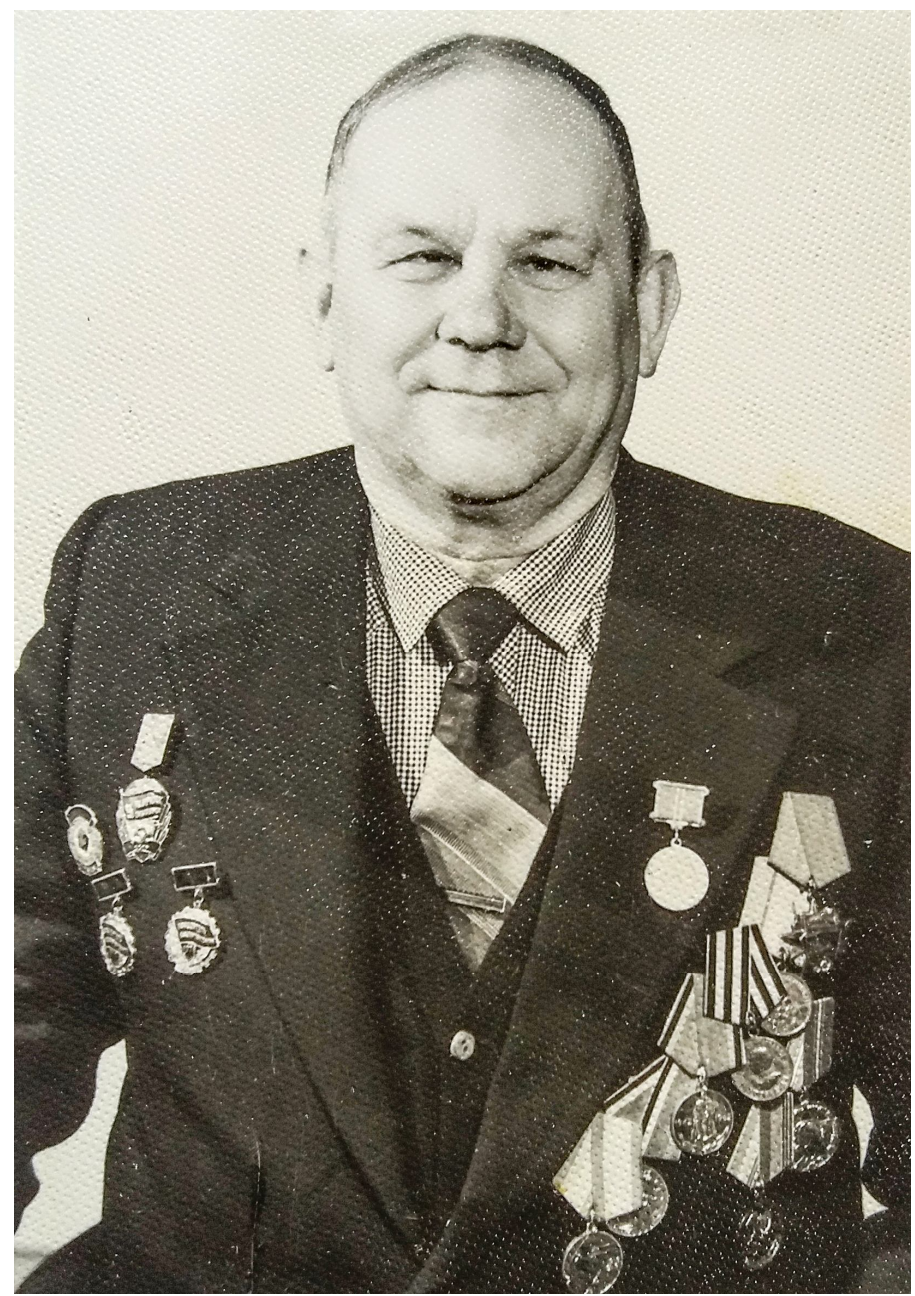

Рис. 21. Олександр Соболь (1920-2004) (родинний архів)

У роки Другої світової війни двоє синів Олени Григорівни Соболь загинуло: у 1941 р. - під Смоленськом Володимир, 1943 р. - Віктор на Дніпрі.

Трагічно склалася доля Олениного чоловіка Андрія Соболя. У вересні 1941 р. його було мобілізовано до Червоної Армії та направлено у м. Ніжин Чернігівської області. Звідки його було переведено до Лубен Полтавської області, де він потрапив у полон. Нацисти після допитів його відпустили додому. На сході Андрія Соболя було обрано старостою села Кустолові Кущі Кобеляцького району Полтавської області (до якого належав хутір Ісаївка), ним він працював два роки з вересня 1941 по серпень 1943 р. ${ }^{17}$ До обов'язків Андрія Соболя відносилося забезпечення продовольством німецької армії, боротьба 3 партизанським рухом у селі, допомога та сприяння нацистам у всьому. Після вигнання нацистів у жовтні 1943 р. військовим трибуналом Андрія Соболя було засуджено як зрадника i

\footnotetext{
${ }^{17}$ Архів УСБУ в Полтавській області. Спр. 17297. Арк. 6-6зв.
} 
8 грудня 1943 р. розстріляно у Полтаві ${ }^{18}$. Його майно було конфісковано на корить держави.

Питання колаборації і роки Другої світової війни залишається дискусійним і неоднозначним нині серед дослідників. Після вигнання нацистів на допитах Андрій Соболь пояснював це тим, що не вірив у перемогу Червоної Армії, а тому й співпрацював з нацистами. Очевидно, що були й інші давні обра́зи на радянську владу - у його дружини Олени Юркевич-Сокологорської як поміщиці відібрали всю власність - землю, господарство, золото, гроші. Загибель брата Захара Соболя, який чинив опір радянській владі. Згодом родина Соболів змушена була тікати з села на Дніпропетровщину. Трагічні роки Голодомору 1932-1933 pp. і смерть батька Якова, Великий терор 1937-1938 pp. і смерть матері, постійні злидні та страх за майбутнє родини. Такі обставини штовхали людей на співпрацю $з$ нацистськими окупантами.

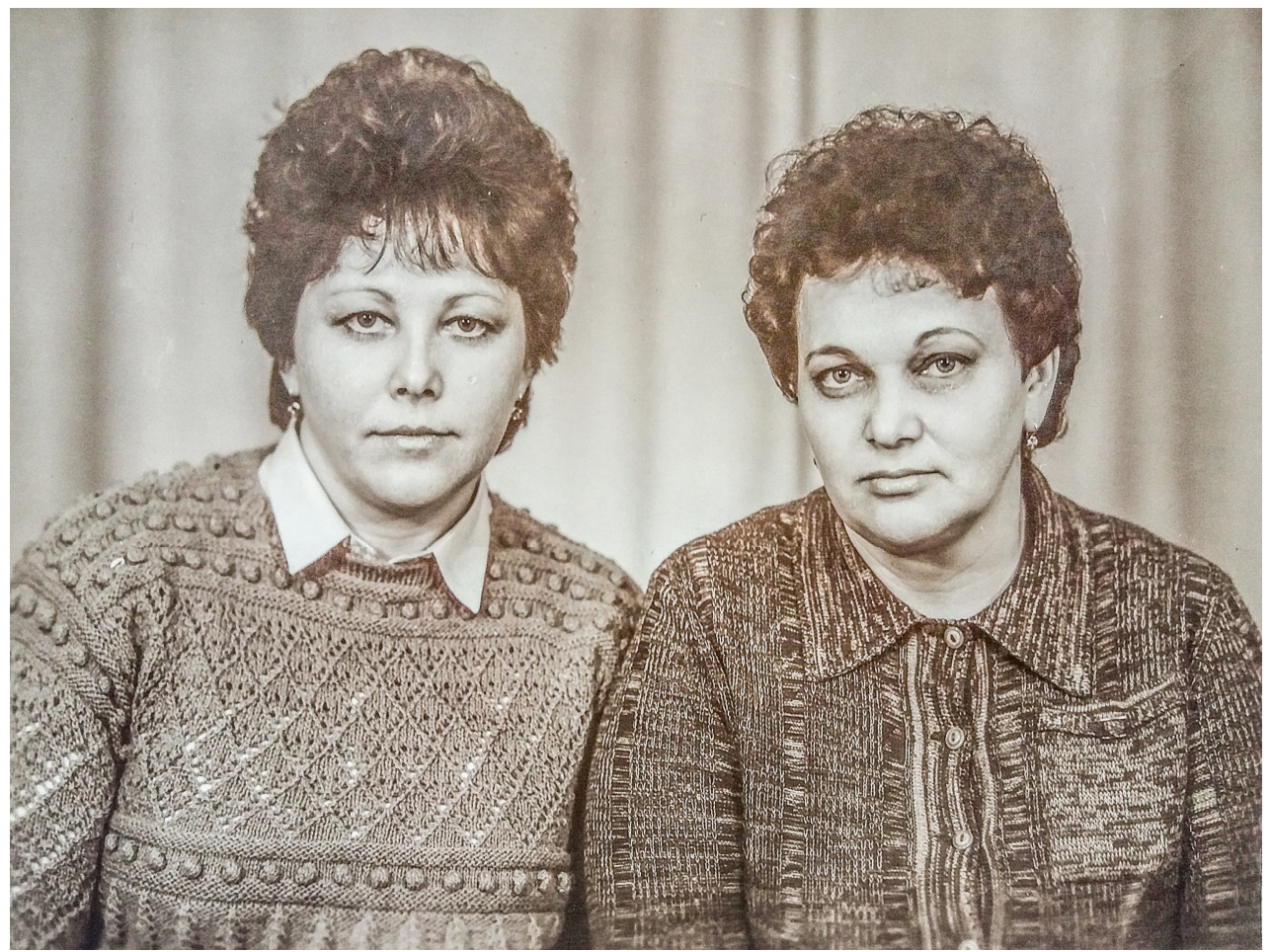

Рис. 22. Любов (справа) і Світлана Соболь (родинний архів)

Родовий маєток Юркевич-Сокологорських опинився у власності держави, згодом він занепав, перетворився на руїни і нині від нього ніякого сліду не лишилося. Олена Соболь 3 дітьми переселилася жити у свій будинок, який ій колись купила мати Віра Василівна, коли дочка побралася з Тихоном Киричко.

Олена Соболь залишилася вдовою фактично без засобів до існування. Їй допомагали діти, які згодом створити власні родини, але ніколи не залишали матір.

${ }^{18}$ Архів УСБУ в Полтавській області. Спр. 17297. Арк. 19. 
Будинок родини Соболь і нині стоїть у хуторі Ісаївка. Цікавою видається його історія. Починав його будівництво батько Тимошенко для своїх синів, завершувало вже подружжя Олени Юркевич-Сокологорської і Тихона Киричко. Після смерті Тихона в ньому проживала Олена зі своїм другим чоловіком Андрієм Соболем.

У повоєнний час будинок було поділено на три частини: в центральній кімнаті проживала Олена Григорівна; зліва, в одній кімнаті - син Михайло; а справа у двох кімнатах - син Олександр. У 1963 р. Олександр Соболь у смт. Біликах збудував свій будинок і перебрався туди жити з родиною, забравши із собою матір. у будинку залишався жити Михайло Соболь, а коли він перебрався до смт. Білики, у будинку до кінця 1970-х років мешкав із родиною його син Юрій. Згодом і він переїхав теж жити у смт. Білики.

Про Олену Григорівну Соболь спогадами поділилася її онука Любов Соболь, яка розповіла, що бабусю у селі називали «бариня», адже вона поведінкою, манерами та зовнішнім виглядом відрізнялася від односельців. Простих селян жінка навчала грамоті читати і писати; була доброзичливою, доброю, спокійною. У смт. Білики Олена Григорівна Соболь ходила в кіно, завжди брала з собою ридикюль, куди клала гаманець, окуляри та хустинку. Вона завжди виглядала вишукано та велично.

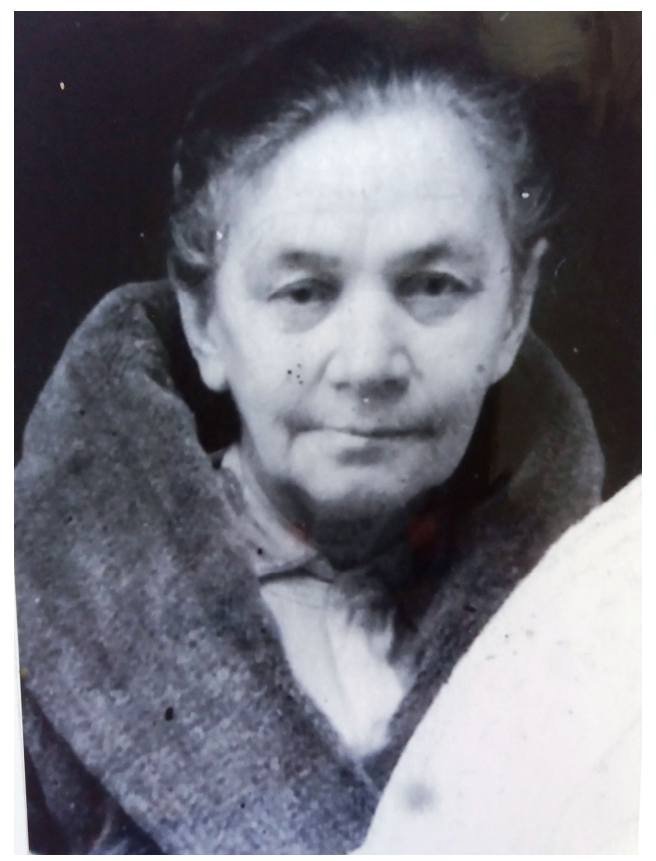

Рис. 23. Олена Григорівна Соболь у віці 70 років (родинний архів)

Олена Соболь на землі не працювала, але чудово готувала і мала смак у харчах, особливо у неї вдавалася випічка. Жінка в'язала крючком чудові речі - серветки, скатертини, хустки тощо, які потім продавалися, що часто рятувало родину від голоду. Олена Григорівна Соболь померла у 1974 р. і похована на цвинтарі у смт. Білики.

У 1979 р. будинок Соболів в Ісаївці придбала родина Россохіних. Іван Россохін прибув із м. Череповець Російської Федерації. Після роботи на шкідливому підприємстві його 
сім'я потребувала відновлення, тож чисте повітря соснових лісів, екологічно чиста зона Ісаївки сприяли цьому. 1982 року будинок було обкладено білою цеглою.

У березні 2000 р. будинок придбав Анатолій Ратаєв, який прибув зі Львова, але його родове коріння було на Кобеляччині. Він зі своєю родиною і нині проживає в цьому будинку й активно займається громадською діяльністю.
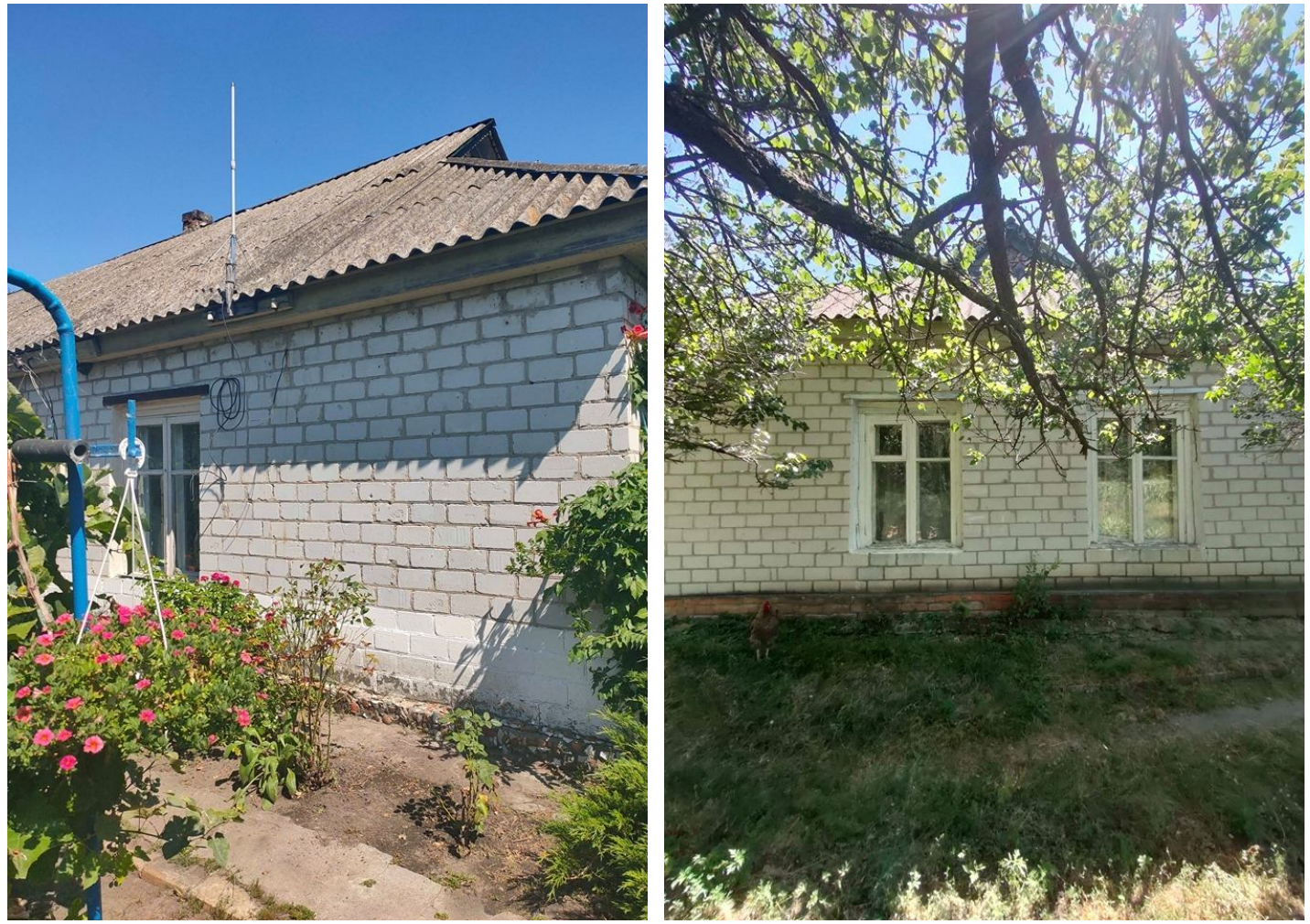

Рис. 24. Будинок Юркевич-Сокологорських. Сучасний вигляд. Фото Ірини Бондар (нерідної доньки Анатолія Ратаєва). 2020 р.

Отже, нащадки сім'ї Юркевич-Сокологорських пам'ятають своє коріння. Представники родини зберігають сімейну історію, сімейні архіви - документи, фото, речі. Будинок Олени Юркевич-Сокологорської на хуторі Ісаївка стоїть і є свідком багатьох історичних подій. Захоплення викликає постать дворянки Олени Юркевич-Сокологорської, яка мала сміливий і вольовий характер, наважилась двічі вийти заміж за простолюдинів і народити від них дітей. Це був рішучий вчинок, який йшов урозріз із суспільними нормами, думкою матері. На долю цієї жінки випали трагічні події: розлучення батьків у дитинстві дівчини, двічі була вдовою, смерть дітей, бідність, позбавлення всього майна радянською владою, Голодомор 1932-1933 років, Друга світова війна, повоєнна відбудова й ін. Незважаючи на це, Олена Юркевич-Сокологорська ніколи не опускала руки, була аристократкою до кінця життя, що виявлялося ззовні і зсередини. Ї̈̈ життя - це приклад стійкості, мужності, незламності духа, внутрішнього спротиву трагічним життєвим обставинам. 
Зберігаймо, збираймо та пам'ятаймо родинну історію. Історія кожної сім'ї - це маленькі шматочки мозаїки, з яких твориться історія України, яка базується на історії родів (!).

Подяки. Сердечно дякую Анатолію Ратаєву з хутора Ісаївка, родині Соболь з села Білики Кобеляцького району Полтавської області за сприяння у підготовці даної розвідки, зокрема, письмові й усні спогади, інтерв'ю, фото, які використані у статті.

Iryna Petrenko

\section{History of the Yurkevych-Sokologorsky in the history of the Kobeliatsk' land in Poltava region}

Abstract: The article deals with the history of the noble family of YurkevichSokologorsky, who lived in the village of Isaivka (belonged to the village of Kustolov Kushchi) Kobeliatsky district of Poltava province. The Sokologorsky house has survived to the present day and is a witness to many historical events. The figure of the noblewoman Olena Yurkevych-Sokologorska, who had a bold and strong-willed character, dared to marry commoners twice and have children from them, is admirable.

This woman suffered tragic events: the divorce of her parents as a child, she was twice a widow, the death of children, poverty, deprivation of all property by the Soviet authorities, the Holodomor of 1932-1933, World War II, postwar reconstruction and others. Despite this, Olena Yurkevych-Sokologorska never gave up, she was an aristocrat for the rest of her life. Her life is an example of resilience, courage, steadfastness of spirit, inner resistance to tragic life circumstances. The memory of their family is still preserved by the descendants of the Sokologorsky family.

Let's save, collect and remember family history. The history of each family is small pieces of a mosaic from which the history of Ukraine which is based on the history of sorts is created (!).

Keywords: Yurkevich-Sokologorsky, nobles, landowners, Poltava province, ancestral estate 